Jurnal CULTURE (Culture, Language, and Literature Review), 8(1), Mei 2021, 17-30

Copyright (C) 2021, Jurnal CULTURE (Culture, Language, and Literature Review), e-ISSN 2775-4618, p-ISSN 2355-8660

\title{
Analisis Motivasi Belajar Bahasa Inggris Mahasiswa Fakultas Bahasa dan Budaya UNTAG Semarang
}

\author{
Gurendi Wiwoho'), Widiarsih Mahanani'), ${ }^{2}{ }^{1}$ uslimah ${ }^{3)}$ \\ Faculty of Language and Culture, UNTAG Semarang \\ email: rendiwiwoho@yahoo.co.id
}

\begin{abstract}
Abstrak
Penelitian yang berjudul "Analisis Motivasi Belajar Bahasa Inggris Mahasiswa Fakultas Bahasa dan Budaya Untag Semarang” bertujuan menganalisis motivasi belajar Bahasa Inggris mahasiswa di FBB Untag Semarang. Faktor-faktor yang dianalisis adalah orientasi, sikap dan lingkungan. Penelitian ini menggunakan pendekatan deskriptif kualitatif. Hasilnya menunjukkan bahwa orientasi mahasiswa untuk belajar bahasa Inggris sangatlah positif dan secara umum mahasiswa yang telah menentukan pilihan mereka mengambil jurusan bahasa Inggris cukup memiliki kemauan untuk belajar dan tidak terlalu menutup diri dari komunikasi serta lingkungan belajar yang sangat mendukung. Ketiga faktor tersebut menunjukkan bahwa motivasi belajar bahasa Inggris mahasiswa FBB Untag Semarang sangatlah tinggi.

Kata kunci: Motivasi Belajar, Orientasi, sikap, Lingkungan Belajar
\end{abstract}

\section{Pendahuluan}

Bahasa merupakan alat komunikasi antara individu satu dengan individu yang lainnya. Oleh karena itu tiap individu harus menguasai bahasa, minimal bahasanya yang digunakan sehari-hari. Seiring dengan perkembangan ilmu pengetahuan dan teknologi, bahasa menjadi sangat penting dalam menunjang perkembangan ilmu pengetahuan dan teknologi. Selain bahasa ibu, bahasa Inggris sangat diperlukan dalam kepentingan ilmu pengetahuan, teknologi dan perdagangan.

Dari sekian banyak bahasa yang ada di dunia ini, ada beberapa bahasa yang amat diperlukan untuk mempermudah komunikasi antar berbagai bangsa, antara lain yaitu bahasa Inggris, bahasa Jepang, bahasa Cina (Mandarin), bahasa Jerman, dan bahasa Perancis. Dengan menguasai lebih dari satu bahasa tersebut di atas maka individu memiliki peluang untuk menambah pengetahuan, menjalin kerjasama dengan bangsa lain, meningkatkan SDM-nya sendiri dan masih banyak manfaat lainnya.

Diantara beberapa bahasa yang tersebut di atas, bahasa Inggris, bahasa Mandarin, dan bahasa Jepang tergolong paling banyak pemakainya, terutama bahasa Inggris yang memang disepakati sebagai bahasa internasional. Sedangkan bahasa Mandarin dan bahasa Jepang dalam 
hubungan perdagangan antar negara juga digunakan. Hal ini terjadi karena ekonomi dunia terutama di kawasan Asia hampir seluruhnya dikuasai oleh Cina dan Jepang, bahkan produkproduk dari Cina dan Jepang juga masuk pasar Eropa maupun Amerika.

Akibatnya sekarang ini semakin banyak orang yang belajar bahasa Inggris, bahasa Jepang dan bahasa Cina. Hal inilah yang membuat lembaga perguruan tinggi dan lembaga kursus untuk membuka kelas bahasa Inggris, bahasa Jepang dan bahasa Cina dengan jumlah pesertanya yang semakin bertambah. Menurut pengamatan, khususnya di Semarang telah dibuka perguruanperguruan tinggi baik jenjang S1 maupun Diploma yang membuka jurusan bahasa Inggris dan bahasa Jepang. Ini membuktikan bahwa bahasa Jepang mulai diminati meskipun jumlah peminatnya belum begitu besar seperti bahasa Inggris. Berdasarkan pertimbangan ini maka peneliti membatasi permasalahan pada mahasiswa jurusan bahasa Inggris dan non bahasa Inggris, yang dalam hal ini bahasa Jepang.

Namun demikian yang masih menjadi permasalahan sampai saat ini terutama dari lingkungan perguruan tinggi swasta di Semarang yang membuka jurusan bahasa Inggris adalah minat belajar mahasiswa yang masih tergolong rendah. Contohnya, di Fakultas Bahasa dan Budaya (FBB) Universitas 17 Agustus 1945 Semarang tempat peneliti mengajar, kecenderungan mahasiswa menggunakan bahasa daerah atau bahasa Indonesia dalam komunikasi sehari-hari di lingkungan kampus masih sangat jelas terlihat. Kebiasaan ini tentunya tidak menunjang belajar bahasa Inggris khususnya dalam bentuk verbal padahal seharusnya mereka sadar bahwa kelancaran berbicara hanya bisa dicapai oleh mereka apabila mereka sering berlatih berbicara dalam bahasa Inggris.

Dalam upaya mengatasi masalah motivasi belajar, salah satu langkah penting yang perlu diambil yaitu mengkaji besarnya motivasi belajar bahasa Inggris melalui faktor-faktor yang dianggap bisa mempengaruhinya. Ada berbagai faktor yang bisa mempengaruhi seseorang belajar bahasa Inggris. Faktor-faktor tersebut bisa bersifat internal, yaitu faktor-faktor dari dalam diri pembelajar, dan faktor eksternal, yaitu faktor-faktor dari luar pembelajar. Salah satu faktor internal yang penting yaitu orientasi, yang mengacu pada dorongan mempelajari bahasa Inggris karena adanya tujuan-tujuan atau kebutuhan seperti misalnya untuk kemajuan karir, sebagai sarana untuk menguasai bidang-bidang ilmu lain, atau untuk tujuan integratif, yaitu kebutuhan menguasai bahasa Inggris untuk berintegrasi dengan masyarakat pengguna bahasa Inggris tersebut. 
Faktor internal lain yang bisa mempengaruhi motivasi belajar bahasa Inggris yaitu sikap. Ketidaksediaan untuk berkomunikasi, penghindaran dari komunikasi sebagai wujud sikap yang disebabkan oleh sifat introversi, pengalaman-pengalaman buruk atau karena faktor-faktor lain dianggap bisa menghambat pencapaian prestasi dalam proses belajar. Apabila seseorang dalam belajar bahasa Inggris banyak menghadapi suasana-suasana ketegangan atau pengalamanpengalaman buruk bisa menyebabkan keputusasaan maka keputusasaan itu bisa melemahkan motivasinya untuk mempelajari bahasa Inggris. Sebaliknya apabila seseorang menyukai atau tertarik dengan bahasa Inggris, seberapapun besar kesulitannya, justru semakin mendorongnya untuk mempelajari bahasa Inggris tersebut karena pada dasarnya suka dengan hal-hal baru dan suka tantangan-tantangan. Jadi sikap seseorang dalam belajar bahasa Inggris dianggap bisa mempengaruhi dorongannya untuk mempelajari bahasa Inggris tersebut.

Faktor eksternal atau lingkungan belajar juga dianggap bisa mempengaruhi motivasi seseorang dalam belajar bahasa inggris. Faktor lingkungan mengacu pada unsur-unsur di luar diri pembelajar, seperti: peluang-peluang yang dimiliki untuk berinteraksi, ketersediaan bantuan sarana dan prasarana, sumber-sumber yang ada, perhatian dari pengajar, metode pendekatan yang digunakan pengajar dan iklim atau suasana belajar. Unsur-unsur tersebut baik secara individual maupun bersama-sama dianggap bisa mempengaruhi motivasi belajar seseorang. Misalnya, iklim belajar yang kooperatif, suportif dan nyaman ditambah dengan ketersediaan bantuan dan metode yang tepat yang digunakan pengajar sebagai motivator sangat mendukung dalam mengatasi motivasi belajar mahasiswa.

Penelitian ini membahas bagaimaa motivasi belajar bahasa Inggris mahasiswa FBB Untag Semarang berdasar pada faktor internal yaitu orientasi dan sikap serta faktor eksternal yaitu lingkungan.

\section{Landasan Teori}

Bahasa ibu merupakan bahasa yang mudah dipahami dan dipraktekkan. Hal ini karena bahasa ibu diperoleh sejak lahir dan dipakai untuk komunikasi sehari-hari, dengan orang tua, teman atau orang-orang lain yang mempunyai bahasa ibu yang sama. Akan tetapi akan berbeda kalau belajar bahasa inggris, bahasa Jepang, bahasa Cina maupun bahasa asing yang lain. Tentunya proses belajar tersebut akan berlangsung lebih lambat dan sering banyak menghadapi kendala-kendala. 
Analisis Motivasi Belajar Bahasa Inggris Mahasiswa Fakultas Bahasa dan Budaya UNTAG Semarang (Gurendi Wiwoho, Widiarsih Mahanani, Muslimah)

Untuk dapat menguasai bahasa Inggris, yang tidak digunakan dalam komunikasi seharihari, diperlukan dorongan atau motivasi dan minat yang kuat dari pembelajar karena hal tersebut merupakan penggerak yang mengaktifkannya dalam melakukan tindakan-tindakan atau upaya untuk mencapai tujuan tersebut. Untuk meningkatkan motivasi belajar tersebut ada beberapa faktor yang mempengaruhi baik berasal dari dalam individu (internal) dan dari luar individu (eksternal)

\subsection{Motivasi Belajar}

Kata "motivasi” berasal dari bahasa Inggris "motivation" yang berarti dorongan. Menurut Brown (1987) motivasi adalah "Sebagai alasan dasar, pikiran dasar, dorongan seseorang untuk berbuat atas ide pokok yang selalu berpengaruh terhadap tingkah laku manusia". Sementara William G Scoot mengartikan motivasi "Sebagai keadaan dalam pribadi seseorang yang mendorong keinginan individu untuk melakukan kegiatan-kegiatan tertentu guna mencapai tujuan". (Zaenun, 1979:10). Setiap manusia untuk melakukan sesuatu biasanya disebabkan oleh adanya suatu dorongan, dimana dengan dorongan tersebut manusia akan mendapatkan apa yang diinginkan. Motivasi disini mengandung pengertian yaitu keinginan yang terdapat pada seorang individu yang merangsang untuk melakukan tindakan-tindakan (George.R, 1986: 328).

Seperti dikemukakan di atas, motivasi adalah dorongan seseorang melakukan suatu tindakan. Jadi motivasi belajar adalah dorongan pada diri seseorang untuk belajar. Dalam kaitannya dengan pembelajaran bahasa kedua (bahasa Inggris), Gardner (1985:10) secara eksplisit mendefinisikan motivasi belajar bahasa kedua sebagai "the extent to which the individual works or strives to learn the language because of a desire to do so and the satisfaction experienced in this activity", yang bila diterjemahkan kurang lebih sebagai "tingkatan upaya atau tindakan seseorang untuk mempelajari bahasa karena didorong oleh keinginan yang kuat untuk mempelajari bahasa itu”. Definisi Gardner tersebut mencakup tiga hal: Upaya (effort) yang dikerahkan untuk mencapai suatu tujuan; Keinginan (desire) untuk mempelajari bahasa; dan (satisfaction) dalam mempelajari bahasa tersebut. Oleh karena itu motivasi belajar bahasa Inggris seseorang bisa diukur melalui tingkat upaya yang dikerahkan untuk menguasai bahasa Inggris itu. Sedangkan harapan (desire) dan (satisfaction) merupakan faktor yang mendorong melakukan upaya tersebut.

Motivasi juga sering dibedakan antara motivasi intrinsik dan motivasi ekstrinsik, tergantung pada apakah stimulus dari perilaku berasal dari diri individu (intrinsik) atau dari luar 
Jurnal CULTURE (Culture, Language, and Literature Review), 8(1), Mei 2021, 17-30

Copyright $\odot$ 2021, Jurnal CULTURE (Culture, Language, and Literature Review), e-ISSN 2775-4618, p-ISSN 2355-8660

individu (ekstrinsik). Van Lier (1996:101) dan Csiksdzentmihalyi \& Rathunde (1993) berpendapat bahwa kebanyakan teori-teori motivasi memfokuskan pada sumber-sumber motivasi itu dari masa lalu dan akan datang (extrinsic), dengan mengabaikan motivasi intrinsik yang muncul ketika terjadi keseimbangan antara ketrampilan bahasa dan tantangan-tantangannya, dan pembelajar merasakan adanya pada aktivitas itu sendiri lebih lanjut Csikszentmihalyi (1990:250), bagaimanapun juga menunjukkan ada 32 macam teori motivasi yang memfokuskan pada masa sekarang (present), dan tidak berorientasi pada pengaruh-pengaruh masa lalu atau masa mendatang terhadap motivasi.

Dari definisi-definisi di atas bisa disimpulkan bahwa manusia akan melakukan sesuatu yang diinginkan karena adanya suatu dorongan dalam mencapai suatu tujuan tertentu. Dengan demikian motivasi adalah dorongan dari dalam pribadi seseorang yang mendasari suatu tindakan. Jadi apabila seseorang belajar bahasa Inggris tentu ada sesuatu yang mendorongnya untuk belajar bahasa Inggris tersebut, misalnya untuk menguasai ilmu pengetahuan, untuk meningkatkan karir, atau untuk berintegrasi dengan masyarakat pengguna bahasa Inggris tersebut, dan lain sebagainya.

\subsection{Faktor-faktor yang Mempengaruhi Keberhasilan Belajar}

Dalam kaitan dengan konteks keberhasilan belajar, ada beberapa faktor yang berperan dan turut mempengaruhi keberhasilan dalam proses belajar, termasuk dalam belajar bahasa Inggris. Karena bahasa Inggris sebagai bahasa wajib yang diajarkan dari sekolah menengah sampai perguruan tinggi dan bagi banyak pembelajar bahasa Inggris ini masih dianggap sebagai momok yang berakibat pada kurang kemauan untuk belajar. Sikap inilah yang menyebabkan mereka tidak menerima kesulitan-kesulitan sebagai tantangan melainkan sebagai ssuatu yang harus dihindari. Namun demikian secara garis besar keberhasilan belajar bahasa Inggris tidak sepenuhnya dari faktor diri pembelajar melainkan juga faktor-faktor luar yang turut mempengaruhi motivasi mereka untuk belajar.

Faktor dari dalam diri siswa besar sekali pengaruhnya terhadap hasil belajar yang dicapai. Menurut Clark yang dikutip oleh Sudjana (2004: 39) "mengatakan bahwa hasil belajar siswa di sekolah $70 \%$ dipengaruhi oleh kemampuan siswa dan $30 \%$ oleh lingkungan”. Pengaruh dari dalam diri siswa merupakan hal yang wajar sebab hakikat perbuatan belajar menurut Sudjana (2004: 40) yaitu:"perubahan tingkah laku individu yang diniati dan disadarinya". Dengan demikian seorang siswa harus berusaha mengerahkan segala daya dan upaya untuk mencapai 
hasil belajar yang memuaskan. Sedangkan faktor dari luar diri siswa juga dapat menentukan atau mempengaruhi hasil belajar yang dicapainya. Hal ini terkait dengan pendapat Caroll yang dikutip Sudjana (2004: 40) bahwa: "Hasil belajar yang dicapai siswa dipengaruhi oleh lima faktor, yakni (a). Bakat pelajar, (b) waktu yang tersedia untuk belajar, (c) Waktu yang diperlukan siswa untuk menjelaskan pelajaran, (d) Kualitas pengajaran dan (e) Kemampuan individu”.

Bagaimanapun motivasi itu sendiri bukan sesuatu yang statis melainkan sesuatu yang dinamis, bisa berubah-rubah karena situasi dan kondisi baik internal maupun eksternal. Berdasar pemikiran itu Dörnyei (1990) mengidentifikasikan faktor-faktor yang menumbuhkan motivasi seperti ketertarikan pada bahasa Inggris, budaya dan masyarakatnya; keinginan untuk memperluas wawasan, keinginan akan tantangan-tantangan dan stimuli baru, Sementara Williams \& Burden (1997:121) menyajikan sebuah model terdiri dari tiga komponen yang saling tergantung sebagai faktor-faktor yang terlibat dalam motivasi dalam konteks sosial seperti bagan berikut ini :
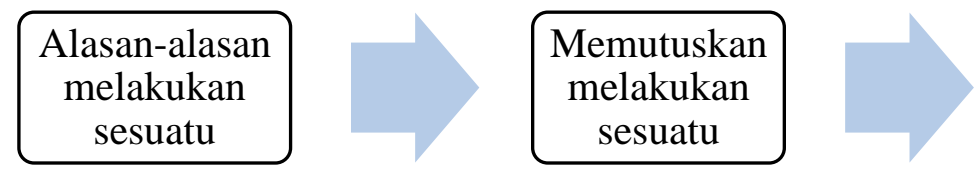

Menjaga atau memelihara

Faktor-Faktor Motivasi Dalam Konteks Sosial

Dalam model ini, "keputusan untuk bertindak bersifat sentral, berinteraksi secara dinamis dengan faktor-faktor eksternal seperti sifat-sifat interaksi faktor-faktor lain, lingkungan belajar, dan faktor-faktor internal seperti ketertarikan akan aktivitas, persepsi nilai aktivitas, sebagai agen, penguasaan, konsep diri, sikap, faktor-faktor afektif lain, usia dan jenis kelamin.

Karena banyaknya faktor serta kompleksitas dari aspek-aspek yang mempengaruhi maka di sini akan dibatasi tiga aspek yang dianggap memiliki korelasi dengan kondisi di Indonesia pada umumnya dalam konteks pembelajaran bahasa Inggris, yang meliputi faktor internal dan faktor eksternal. Faktor internal dalam hal ini dibagi dalam aspek orientasi belajar dan sikap belajar sedangkan faktor eksternal yang akan dibahas keterkaitannya dengan motivasi belajar bahasa Inggris adalah lingkungan belajar.

\subsubsection{Orientasi Belajar}

Orientasi dalam hal ini mengacu pada tujuan yang mendasari seseorang mempelajari bahasa Inggris sebagai bahasa Inggris. Menurut Gardner dan Lambert (1972), mengemukakan 
Jurnal CULTURE (Culture, Language, and Literature Review), 8(1), Mei 2021, 17-30

Copyright (C) 2021, Jurnal CULTURE (Culture, Language, and Literature Review), e-ISSN 2775-4618, p-ISSN 2355-8660

adanya dua jenis orientasi yang memotivasi seseorang mempelajari bahasa Inggris, yakni orientasi instrumental dan integratif. Seseorang dikatakan memiliki orientasi instrumental karena mempunyai tujuan belajar bahasa Inggris untuk dipakai alat mencapai tujuan tertentu, yakni mencari pekerjaan dan sejenisnya, sedangkan orientasi integratif mengandung pengertian bahwa pembelajar betul-betul ingin menguasai bahasa Inggris untuk kepentingan bahasa itu sendiri, sehingga hasil akhir mereka benar-benar terintegrasi dengan nuansa bahasa tersebut.

Menurut teori kebutuhan disebutkan bahwa hal paling mendasar yang menimbulkan motivasi adalah kebutuhan untuk mencapai prestasi (Crandall, 1963). Menurutnya, rasa takut gagal itu biasanya timbul dari situasi-situasi dimana prestasi menjadi fokus tujuannya. Pendapat ini konsisten dengan teori harapan menurut Heckhause (1991) yang mengemukakan bahwa perilaku seseorang merupakan cerminan dari tujuan-tujuan yang ditetapkan. Semakin tinggi harapan bahwa perilaku itu akan menghasilkan suatu hasil yang diharapkan maka akan semakin tinggi pula motivasinya. Selanjutnya Bandura (1989) mengemukakan bahwa hal terpenting adalah sikap seseorang akan kapasitasnya untuk mencapai suatu tingkat prestasi. Kerangka pemikiran seperti ini biasanya terbatas pada lingkup akademis dimana prestasi menjadi tuntutan utama yang perlu dicapai mahasiswa dalam kegiatan belajarnya. Jadi bila seoang mahasiswa mengambil jurusan bahasa Inggris maka ia dituntut untuk bisa mencapai prestasi optimal dalam kemampuan bahasa Inggris tersebut.

Berdasar pendapat-pendapat di atas bisa dikemukakan di sini bahwa dorongan seorang pembelajar di dalam pembelajaran bahasa Inggris timbul karena adanya semacam 'desakan', yang menurut Klein (1986) disebut sebagai 'propensity'. Secara teoritis propensity ini dibagi menjadi 4 unsur yaitu 'kebutuhan komunikatif', 'integritas sosial', demi menunjukkan 'sikap' dan demi tujuan 'pendidikan',

\subsubsection{Sikap Belajar}

Sikap belajar dapat diartikan sebagai kecenderungan perilaku ketika ia mempelajari halhal yang bersifat akademik. Perubahan sikap dapat diamati dalam proses pembelajaran, tujuan yang ingin dicapai, keteguhan, dan konsistensi terhadap sesuatu. Penilaian sikap adalah penilaian yang dilakukan untuk mengetahui sikap peserta didik terhadap mata pelajaran, kondisi pembelajaran, pendidik, dan sebagainya. Menurut Fishbein dan Ajzen dalam Sabri (1996) sikap adalah suatu predisposisi yang dipelajari untuk merespon secara positif atau negatif terhadap suatu objek, situasi, konsep, atau orang. Sikap peserta didik terhadap objek misalnya sikap 
terhadap sekolah atau terhadap mata pelajaran. Sikap peserta didik ini penting untuk ditingkatkan.

Dengan kata lain sikap belajar merupakan dorongan dalam diri seseorang dalam kegiatan yang berhubungan dengan akademik dimana perilaku ini didapatkan dari pengalamanpengaaman dalam hidupnya yang akan mengarah kepada perilaku yang baik maupun yang tidak baik dan senang maupun tidak senang

\subsubsection{Lingkungan Belajar}

Lingkungan belajar dianggap sebagai faktor eksternal, yaitu kondisi di luar diri pembelajar yang bisa mempengaruhi motivasi belajarnya. Berkaitan dengan lingkungan belajar Mantle dan Bromley (1995:383) menekankan pentingnya iklim yang positif karena menurutnya betapapun bagusnya kurikulum yang diterapkan, tanpa dibarengi dengan iklim belajar yang positif maka mahasiswa hanya akan memperoleh sedikit atau bahkan tidak akan memperoleh apa-apa. Iklim belajar yang positif tersebut menurut Legutke dan Thomas (1991) antara lain ditandai dengan iklim saling percaya, bentuk-bentuk interaksi antar parner, situasi-situasi belajar yang menstimulasi interaksi, dan suasana-suasana yang memupuk kreativitas dalam bereksplorasi dengan memelakukan kontak dengan dunia luar.

Sementara Pine \& Boy (1977) menyebutkan adanya tujuh ciri lingkungan belajar yang dianggap menunjang keberhasilan dalam proses belajar sebagai berikut:

Ketersediaan materi-materi yang bermakna dan relevan; Kebebasan berekspresi; Materimateri yang menuntut interaksi dan investigasi; Tidak mengharuskan sikap kompetisi; Kebebasan membuat kesalahan namun tetap percaya diri; Keleluasaan untuk bersosialisasi, keterlibatan emosi dan mengembangkan intelektualitas melalui pekerjaan baik sebagai indivu maupun sebagai bagian dari kelompok dan situasi-siatuasi belajar yang beraneka ragam; Suasana saling menghormati, saling percaya, saling mengasihi, dan saling kepedulian satu sama lain dimana peranan guru sebagai fasilitator dalam proses belajar.

Berdasarkan uraian-uraian di atas mengenai iklim belajar bisa kita simpulkan bahwa iklim belajar memegang peranan penting dalam membangkitkan motivasi belajar.

\section{Metode Penelitian}

Penelitian ini menggunakan pendekatan deskriptif kualitatif. Populasi penelitian ini adalah mahasiswa jurusan bahasa Inggris FBB UNTAG Semarang semester I, III, V dan VII tahun ajaran 2020/2021 dengan jumlah 80 mahasiswa. Adapun sampel yang diambil adalah 40 
Jurnal CULTURE (Culture, Language, and Literature Review), 8(1), Mei 2021, 17-30

Copyright (C) 2021, Jurnal CULTURE (Culture, Language, and Literature Review), e-ISSN 2775-4618, p-ISSN 2355-8660

mahasiswa. Penelitian ini menggunakan metode pengumpulan data observasi, wawancara dan questioner yang diisi oleh responden. Adapun tempat penelitian di fakultas Bahasa dan Budaya Untag Semarang.

\section{Hasil dan Pembahasan}

Berdasar hasil dari data penelitian karakteristik responden yang meliputi jenis kelamin dan status responden., maka mengenai jenis kelamin responden, jumlah responden laki-laki yaitu 12 orang mahasiswa atau $20 \%$, sedangkan jumlah responden perempuan yaitu 28 orang mahasiswa atau $80 \%$. Hal ini berarti jumlah responden perempuan lebih banyak dari para responden laki-laki. Adapun mengenai status mahasiswa didapatkan data bahwa jumlah responden murni yang bukan pekerja lebih banyak, yaitu 30 orang (75\%) dibanding mahasiswa yang sambil bekerja yaitu 10 orang (25\%). Hal ini menunjukkan bahwa jurusan bahasa Inggris juga diminati oleh para pekerja yang kemungkinan untuk menunjang karirnya meskipun jumlajnya tidak lebih banyak sebagian besar mahasiswa murni.

Untuk mengetahui tingkat kemampuan bahasa Inggris menurut persepsi responden. bisa diketahui bahwa secara umum reesponden menilai sendiri kemampuan bahasa Inggris mereka antara mampu sampai sangat mampu. Dari hasil angket juga ditunjukkan bahwa tidak ada responden yang menilai diri sendiri tidak mampu atau sangat tidak mampu. Adapun faktor-faktor yang mempengaruhi motivasi belajar bahasa Inggris dapat diperoleh data sebagai berikut:

\subsection{Faktor Intrinsik:}

\subsubsection{Orientasi Belajar}

Untuk mengetahui orientasi atau tujuan dalam belajar bahasa Inggris dapat diperoleh data bahwa yang menyatakan sangat setuju bahwa menguasai bahasa Inggris dapat mengangkat prestise dan integritas dalam dalam kehidupan bermasyarakat sebanyak 18 responden, penguasaan bahasa Inggris sangat diperlukan dan menjadi kebutuhan untuk komunikasi global sebanyak 13 responden dan mempelajari bahasa Inggris menjanjikan prospek yang bagus bagi masa depan responden sebanyak 14 responden.

Mahasiswa yang menyatakan setuju bahwa menguasai bahasa Inggris dapat mengangkat prestise dan integritas dalam dalam kehidupan bermasyarakat sebanyak 12, yang menyatakan setuju penguasaan bahasa Inggris sangat diperlukan dan menjadi kebutuhan untuk komunikasi global sebanyak 20, dan yang menyatakan setuju mempelajari bahasa Inggris menjanjikan 
prospek yang bagus bagi masa depan responden sebanyak 16. Sedangkan yang menyatakan kurang setuju bahwa menguasai bahasa Inggris dapat mengangkat prestise dan integritas dalam dalam kehidupan bermasyarakat sebanyak 6, yang menyatakan kurang setuju bahwa penguasaan bahasa Inggris sangat diperlukan dan menjadi kebutuhan untuk komunikasi global sebanyak 4 dan yang menyatakan kurang setuju bahwa mempelajari bahasa Inggris menjanjikan prospek yang bagus bagi masa depan responden sebanyak 5 .

Adapun yang menyatakan tidak setuju bahwa menguasai bahasa Inggris dapat mengangkat prestise dan integritas dalam dalam kehidupan bermasyarakat sebanyak 4, yang menyatakan tidak setuju bahwa penguasaan bahasa Inggris sangat diperlukan dan menjadi kebutuhan untuk komunikasi global sebanyak 3 dan yang menyatakan tidak setuju bahwa mempelajari bahasa Inggris menjanjikan prospek yang bagus bagi masa depan responden sebanyak 5.

Dari data tersebut dapat disimpulkan bahwa orientasi mempelajari bahasa Inggris responden yang menyatakan positif yaitu sebesar 77,5\% dan yang bersifat ragu-ragu sebesar 12,5\% dan sisanya $10 \%$ menyatakan negatif. Hal ini menunjukan bahwa responden memiliki kesadaran penuh akan pentingnya menguasai bahasa Inggris sebagai bahasa internasional, dan itu cukup konsisten dengan pilihannya untuk mengambil jurusan bahasa Inggris. Sikap ragu-ragu $(12,7 \%)$ diinterpretasikan sebagai sikap bahwa mereka masih dalam taraf eksplorasi dalam mengambil jurusannya. Hal ini memungkinkan mereka pindah jurusan atau tidak melanjutkan studinya di jurusan bahasa Inggris.

\subsubsection{Sikap Belajar}

Untuk mengetahui sikap belajar bahasa Inggris dapat diperoleh data bahwa yang menyatakan sangat setuju bahwa membuka diri (bukan introversi) terhadap berkomunikasi sebanyak 15, yang menyatakan sangat setuju bahwa suka berpartisipasi (bukan menghindar) dalam komunikasi sebanyak 0, dan yang menyatakan sangat setuju bahwa rasa percaya diri, yakin dan mampu berkomunikasi sebanyak 12. Yang menyatakan setuju bahwa membuka diri ( bukan introversi) terhadap berkomunikasi sebanyak 14, yang menyatakan setuju bahwa suka berpartisipasi (bukan menghindar) dalam komunikasi sebanyak 8 , dan yang menyatakan setuju bahwa rasa percaya diri, yakin dan mampu berkomunikasi sebanyak 15 .

Yang menyatakan kurang setuju bahwa membuka diri (bukan introversi) terhadap berkomunikasi sebanyak 9, yang menyatakan kurang setuju bahwa suka berpartisipasi (bukan 
Jurnal CULTURE (Culture, Language, and Literature Review), 8(1), Mei 2021, 17-30

Copyright $\odot$ 2021, Jurnal CULTURE (Culture, Language, and Literature Review), e-ISSN 2775-4618, p-ISSN 2355-8660

menghindar) dalam komunikasi sebanyak 16, dan yang menyatakan kurang setuju bahwa rasa percaya diri, yakin dan mampu berkomunikasi sebanyak 5. Yang menyatakan tidak setuju bahwa membuka diri (bukan introversi) terhadap berkomunikasi sebanyak 2, yang menyatakan tidak setuju bahwa suka berpartisipasi (bukan menghindar) dalam komunikasi sebanyak 10, dan yang menyatakan tidak setuju bahwa rasa percaya diri, yakin dan mampu berkomunikasi sebanyak 5 . Serta yang menyatakan sangat tidak setuju bahwa membuka diri (bukan introversi) terhadap berkomunikasi sebanyak 0, yang menyatakan sangat tidak setuju bahwa suka berpartisipasi (bukan menghindar) dalam komunikasi sebanyak 6, dan yang menyatakan sangat tidak setuju bahwa rasa percaya diri, yakin dan mampu berkomunikasi sebanyak 3.

Berdasar data di atas secara umum mahasiswa yang telah menentukan pilihan mereka mengambil jurusan bahasa Inggris cukup memiliki kemauan untuk belajar dan tidak terlalu menutup diri dari komunikasi. Namun demikian, ada sebagian responden yang merasa kurang percaya diri dengan kemampuannya, atau mereka memang terhambat dengan budaya 'malu' atau takut dianggap 'show-off' yang sebenarnya ini kurang tepat dalam konteks belajar bahasa Inggris yang mengharuskan banyak latihan atau "practice" Dengan kata lain yang bersikap ragu-ragu dan negative mereka menganggap kecemasan yang mereka alami bisa disebabkan oleh dua hal, pertama, karena kekurangpercayaan dengan kemampuannya dan, yang kedua karena rasa takut dianggap 'sok unjuk diri'

\subsection{Faktor Ekstrinsik Yaitu Lingkungan Belajar}

Untuk mengetahui pengaruh lingkungan belajar dapat diperoleh data bahwa yang menyatakan sangat setuju terhadap peluang-peluang berinteraksi sebanyak 10, yang menyatakan sangat setuju terhadap ketersediaan sumber atau materi-materi yang menunjang sebanyak 11, yang menyatakan sangat setuju terhadap ketersediaan sarana penunjang seperti laboratorium bahasa sebanyak 10, yang menyatakan sangat setuju terhadap suasana kompetisi sebanyak 7 , yang menyatakan sangat setuju terhadap adanya umpan balik sebanyak 9, yang menyatakan sangat setuju terhadap kebebasan berekspresi sebanyak 11 dan yang menyatakan sangat setuju terhadap peranan dosen sebagai motivator sebanyak 10. Yang menyatakan setuju terhadap peluang-peluang berinteraksi sebanyak 13, yang menyatakan setuju terhadap ketersediaan sumber atau materi-materi yang menunjang sebanyak 19, yang menyatakan setuju terhadap ketersediaan sarana penunjang seperti laboratorium bahasa sebanyak 19, yang menyatakan setuju terhadap suasana kompetisi sebanyak 13, yang menyatakan setuju terhadap adanya umpan balik 
sebanyak 14, yang menyatakan setuju terhadap kebebasan berekspresi sebanyak 19 dan yang menyatakan setuju terhadap peranan dosen sebagai motivator sebanyak 19.

Yang menyatakan kurang setuju terhadap peluang-peluang berinteraksi sebanyak 10, yang menyatakan kurang setuju terhadap ketersediaan sumber atau materi-materi yang menunjang sebanyak 6, yang menyatakan kurang setuju terhadap ketersediaan sarana penunjang seperti laboratorium bahasa sebanyak 5, yang menyatakan kurang setuju terhadap suasana kompetisi sebanyak 12, yang menyatakan kurang setuju terhadap adanya umpan balik sebanyak 10, yang menyatakan kurang setuju terhadap kebebasan berekspresi sebanyak 6 dan yang menyatakan kurang setuju terhadap peranan dosen sebagai motivator sebanyak 4.

Yang menyatakan tidak setuju terhadap peluang-peluang berinteraksi sebanyak 7, yang menyatakan tidak setuju terhadap ketersediaan sumber atau materi-materi yang menunjang sebanyak 14, yang menyatakan tidak setuju terhadap ketersediaan sarana penunjang seperti laboratorium bahasa sebanyak 6, yang menyatakan tidak setuju terhadap suasana kompetisi sebanyak 8, yang menyatakan tidak setuju terhadap adanya umpan balik sebanyak 7, yang menyatakan tidak setuju terhadap kebebasan berekspresi sebanyak 4 dan yang menyatakan tidak setuju terhadap peranan dosen sebagai motivator sebanyak 7. Adapun yang menyatakan sangat tidak setuju tidak ada sama sekali.

Berdasar data di atas dapat dikatakan bahwa yang menyatakan positif adalah 67,33\%. menyatakan ragu-ragu $17,5 \%$ dan sisanya $14,17 \%$ menyatakan sikap negatif. Hal ini menunjukan bahwa responden secara umum merasa bahwa lingkungan belajar sudah cukup mendukung untuk belajar bahasa asng. Namun demikian sebagian merasa lingkungan belajar mereka kurang mendorong kemauan belajar bahasa $(31,6 \%)$. Keragu-raguan mereka dapat dilihat pada sikap terhadap ketersediaan sarana, ketersediaan sumber, keleluasaan bersosialisasi serta peran dosen sebagai motivator yang menurut mereka masih kurang mendukung. Ini mengindikasikan bahwa dari sebagian mereka masih belum yakin bahwa lingkungan tempat mereka belajar cukup mendukung untuk mendorong mereka berprestasi dan berekspresi.

\section{Simpulan}

Berdasar uraian di atas dapat disimpulkan bahwa: 
1. Orientasi mahasiswa untuk belajar bahasa Inggris sangatlah positif sehingga mendorong mahasiswa memiliki kesadaran penuh akan pentingnya menguasai bahasa Inggris sebagai bahasa internasional.

2. Secara umum sikap mahasiswa yang telah menentukan pilihan mereka mengambil jurusan bahasa Inggris cukup memiliki kemauan untuk belajar dan tidak terlalu menutup diri dari komunikasi.

3. Mahasiswa merasa bahwa lingkungan belajar sudah cukup mendukung untuk belajar bahasa asng, meskipun masih ada sebagian yang merasa lingkungan belajar kurang mendorong kemauan belajar bahasa

4. Motivasi belajar bahasa Inggris mahasiswa FBB Untag Semarang cukup tinggi berdasar ketiga faktor yaitu orientasi, sikap dan lingkungan belajar.

\section{DAFTAR PUSTAKA}

Brown, H. Douglas. 1987. Principles of Learning and Teaching. Prentice Hall:New Jersey. 2-nd Edition

Csikszentmihalyi, M. (1990). Flow: The Psychology of Optimal Experience. New York: Harper \& Row.

Csikszentmihalyi, M. \& Rathunde (1993). dalam J.E. Jacobs (Ed.). Developmental Perspectives on Motivation. Nebraska Symposium on Motivation, 1992, Volume 40. Lincoln, Nebraska: University of Nebraska Press. 57-97.

Dörnyei, Z. (1990). Conceptualizing motivation in foreign-language learning. Language Learning, 40/1, 45-78.

Gardner, R.C. \& Lambert, W.E. (1972). Attitudes and Motivation in Second-Language Learning. Rowley, MA: Newbury House

Gardner, R. C. (1985). Social psychology and second language learning: The role of attitudes and motivation. London: Edward Arnold.

George.R, Asas-asas manajerial (alih bahasa Dr Winardi) Bandung Alumni, 1986

Klein, W. 1986. Second Language Acquisition Cambridge: Cambridge University Press.

Legutke, M \& Thomas. H. (1991) Process and Experience in the Language Classroom. Harlow: Longman

Pine, G.J. \& Boy, A.V. (1977). Learner Centered Teaching: a Humanistic View. Denver, Colorado: Love Publishing Co. 
Analisis Motivasi Belajar Bahasa Inggris Mahasiswa Fakultas Bahasa dan Budaya UNTAG Semarang (Gurendi Wiwoho, Widiarsih Mahanani, Muslimah)

Van Lier, L. (1996). Interaction in the Language Curriculum: Awareness, Autonomy, and Authenticity. London: Longman.

Williams, M. \& Burden, R.L. (1997). Psychology for Language Teachers: A Social Constructivist Approach. Cambridge: Cambridge University Press

Zaenun, Buchari. (1979). Management dan Kecemasan. Balai Aksara . Jakarta. 